\title{
Can Spirulina maxima reduce the mutagenic potential of sibutramine?
}

\author{
R.P. Araldi ${ }^{1,2}$, N.P. Santos ${ }^{3}$, T.B. Mendes ${ }^{4}$, L.B. Carvalho ${ }^{3}$, E.T. Ito ${ }^{3}$, \\ P.L. de-Sá-Júnior ${ }^{1}$ and EB Souza ${ }^{3}$ \\ ${ }^{1}$ Laboratório de Genética, Instituto Butantan, São Paulo, SP, Brasil \\ 2Programa de Pós-Graduação Interunidades em Biotecnologia, \\ Instituto de Ciências Biomédicas, Universidade de São Paulo, São Paulo, SP, Brasil \\ ${ }^{3}$ Laboratório de Genética, Biologia Molecular e Mutagênese, \\ Faculdade de Ciências e Letras de Assis, \\ Universidade Estadual Paulista "Júlio de Mesquita Filho", São Paulo, SP, Brasil \\ 4Programa de Pós-Graduação em Biologia Estrutural e Funcional, \\ Universidade Federal de São Paulo, São Paulo, SP, Brasil
}

Corresponding author: E.B. Souza

E-mail: edislane@assis.unesp.br

Genet. Mol. Res. 14 (4): 18452-18464 (2015)

Received August 12, 2015

Accepted November 26, 2015

Published December 23, 2015

DOI http://dx.doi.org/10.4238/2015.December.23.33

ABSTRACT. The worldwide obesity pandemic requires the use of antiobesity drugs. Sibutramine is an anti-obesity drug that has been used worldwide but is indiscriminately consumed in Brazil. Several studies have demonstrated that sibutramine promotes weight loss and weight maintenance, but several side effects have been associated with its systematic consumption. For this reason, sibutramine was withdrawn from the European and American markets, but still remains legal for use in Brazil. Studies have shown that a $5-10 \%$ reduction in body weight results in outstanding health benefits for obese patients. However, in order to promote significant weight loss, it is necessary to use sibutramine for at least 2 years. This long-term exposure has carcinogenic potential, as sibutramine causes DNA damage. Thus, this study evaluated the in vivo mutagenic potential of sibutramine alone $(5,7,10,15$, and $20 \mathrm{mg} / \mathrm{kg})$ and in association with 
Spirulina maxima (150 and $300 \mathrm{mg} / \mathrm{kg}$ ), a cyanobacterium with antioxidant potential, using the polychromatic erythrocyte micronucleus test. Our results reinforced the mutagenic potential of sibutramine alone, which showed a time-dependent action. Combinatory treatments with S. maxima were not able to reduce the genotoxicity of sibutramine. These results were confirmed in vitro with the cytokinesis-blocked micronucleus test. In conclusion, our data showed that new alternative anti-obesity treatments are needed since the consumption of sibutramine can increase the risk of cancer in overweight patients.

Key words: Anti-obesity drug; Sibutramine; Genotoxicity; Micronucleus; Mutagenesis

\section{INTRODUCTION}

The current obesity pandemic requires the use of anti-obesity agents (Halford, 2011), mainly in selected patients in whom lifestyle modifications have been unsuccessful (Padwal and Majumdar, 2007). In recent decades, numerous drugs have been approved for the treatment of obesity (Kang and Park, 2012); however, most have been withdrawn from the market due adverse side effects (Kang and Park, 2012). Currently, only 2 anti-obesity drugs are licensed, orlistat and sibutramine (Padwal and Majumdar, 2007). Orlistat can reduce weight by around $3 \mathrm{~kg}$, whereas sibutramine results in mean weight losses of $4-5 \mathrm{~kg}$ (Padwal and Majumdar, 2007). The consumption of these drugs is increasing, mainly in developing countries (Carlini et al., 2007). Brazil registers as the primary consumer in the anti-obesity drug market, followed by Argentina and the United States of America (Carlini et al., 2007). Anti-obesity drugs are among the 4 most commonly consumed drugs in Brazil (Carlini et al., 2007; Silva et al., 2010). The easy acquisition of sibutramine, even with prescription obligatory required by Agência Nacional de Vigilância Sanitária (ANVISA) and this lack of moderation results in the high consumption of these drugs (Carlini et al., 2007).

Sibutramine hydrochloride monohydrate is the most common orally administered agent for the treatment of obesity (Silva et al., 2010). This anorexiant was firstly proposed as an antidepressant in the 1980s, as it has a similar mechanism to tricyclic antidepressants (Lee et al., 2008). However, weight loss was observed in obese patients using sibutramine as an antidepressant. This revealed the anorexiant potential of this drug, which quickly gained market appeal and is now sold under the name of Reducti ${ }^{\circledR}$ or Meridia ${ }^{\circledR}$ (Silva et al., 2010). The drug does not have any anticholinergic or antihistaminergic activity and does not stimulate the release of serotonin, noradrenalin or dopamine (Eroglu et al., 2009). Sibutramine is a serotonin and norepinephrine reuptake inhibitor (SNRI) (Eroglu et al., 2009). Thus, the drug increases extracellular serotonin and norepinephrine levels, reducing appetite and, subsequently, food intake (Padwal and Majumdar, 2007). Moreover, the drug improves metabolic fitness, leading to a reduction in levels of triglycerides, total and low-density lipoprotein (LDL) cholesterol, and glycaemia (Nisoli and Carruba, 2000). Sibutramine demethylation produces mono- and di-desmethylsibutramine (M1 and M2), which are distributed in tissues (Eroglu et al., 2009; Silva et al., 2010). The drug reaches its peak concentration in plasma 1-2 $\mathrm{h}$ after ingestion and has a half-life of 14 to $16 \mathrm{~h}$ in humans (Silva et al., 2010).

Several studies provide evidence that sibutramine is effective in promoting weight loss and weight maintenance (Nisoli and Carruba, 2000; Padwal and Majumdar, 2007; Rubio et al., 2007). 
Long-term treatment with sibutramine revealed beneficial effects in controlling hyperlipidemia, blood pressure, and levels of cytokines; together, these resulted in decreased cardiovascular risk in obese patients (Rubio et al., 2007). Short-term therapy with sibutramine, together with diet and lifestyle intervention, improved endothelial function in patients with coronary artery disease (Shechter et al., 2006). Although sibutramine has potential as an anti-obesity treatment, several side effects associated with its use have been demonstrated, including risk of psychosis in children and adolescents (Lee et al., 2008), congenital malformation (teratology) (Garcia-Bournissen et al., 2007), abnormal ejaculation in men with doses of $5-20 \mathrm{mg} / \mathrm{kg}$ (Nojimoto et al., 2009), genotoxicity damage in hematopoietic cells (Silva et al., 2010), and risk of acute myocardial infarction (Eroglu et al., 2009). Sibutramine exerts a peripheral sympathomimetic effect that induces an increase in blood pressure and cardiac frequency, increasing the risk for tachycardia and arrythmia (Padwal and Majumdar, 2007). Thus, use of sibutramine can lead to hypertension, tachycardia, arrhythmia and myocardial infarction (Scheen, 2011). These adverse effects were confirmed by the sibutramine cardiovascular outcome trial (SCOUT), which showed that the drug increases the risk of non-fatal myocardial infarction and stroke in patients with preexisting cardiovascular disease (CVD) submitted to long-term treatment with sibutramine (10-15 mg/day) (Scheen, 2011). For these reasons, the European Medicines Agency (EMA) recommended suspending marketing authorizations for sibutramine in the European Union (Scheen, 2011). The Federal Drug Administration (FDA) also withdrew the drug from the market in 2010 (FDA, 2010). In Brazil, ANVISA allowed for the continual marketing of sibutramine (15 mg/day) and other anti-obesity drugs such as anphepramon, phenproporex, and mazindol with revenue retention (ANIVSA, 2014).

Determining the optimal outcome of sibutramine treatment is important yet time consuming. Long-term treatment with sibutramine can confer carcinogenicity due its potential for mutagenesis. Mutations are considered the first step in carcinogenesis, as they result in genomic instability which is a hallmark of cancer (Fenech, 2000; Araldi et al., 2015). Due to the mutagenic risk associated with the few anti-obesity drugs available, one possible alternative is to reduce the risk of DNA damage through the use of antioxidant drugs together with sibutramine (Silva et al., 2010). One of the potential antioxidants that could be used is Spirulina maxima (Setchell \& N.L. Gardner), a filamentous, planktonic and photosynthetic cyanobacterium of order Nostocales. $S$. maxima is composed of $65 \%$ protein and $30 \%$ essential amino acids (Delay, 2002). In addition, this cyanobacterium has chelated minerals (iron, potassium and magnesium), vitamins (biotin, cyanocobalamin, calcium pantothenate, folic acid, inositol, thiamine, alpha-tocopherol, pyridoxine and riboflavin), phenolic acids, beta-carotene and fatty acids (linoleic and gamma-linolenic acids) (Delay, 2002; Araldi et al., 2014). S maxima is considered the greatest discovery of the 21st century in the nutrition field (Ponce-Canchihuamán et al., 2010). Current studies have also demonstrated the antioxidant and anti-inflammatory potential of S. maxima (Miranda et al., 1998; GutiérrezRebolledo et al., 2015). Moreover, studies have already shown that S. maxima is anti-mutagenic and is compatible with other anorexiant drugs, such as Pholia magra (Araldi et al., 2014).

The micronucleus test (MNT) is an important in vitro and in vivo biomarker, used extensively in toxicological genetics (Samanta and Dey, 2012; Araldi et al., 2015). Micronuclei (MNs) are formed during erythropoiesis in rodent bone morrow (Krishna et al., 2000) or are observed in cytokinesisblocked binucleated lymphocytes (Araldi et al. 2015). The presence of MNs indicate aneugenic and/or clastogenic events, suggesting mutagenic risk (Araldi et al., 2015). For this reason and due the simplicity, versatility and low cost of the MNT, this method has been used since 1959 as a marker of cytogenetic damage (Kirsch-Volders et al., 2003). Moreover, MNT has some advantages 
over the comet assay (CA): it can detect DNA damage in cells both in interphase and mitosis and it is more statistically sound because it requires the analysis of 1000 (in vitro) or 2000 (in vivo) cells (Araldi et al., 2015). This is the first study to evaluate the mutagenic potential of sibutramine alone or together with S. maxima using the polychromatic erythrocyte (PCE) MNT (PCEMNT) in vivo and cytokinesis-blocked MNT (CBMNT) in vitro. Moreover, this study evaluated the mutagenicity of these drugs in mice (in vivo) and human cells (in vitro).

\section{MATERIAL AND METHODS}

\section{PCEMNT}

A total of 102 albino Swiss mice (Mus musculus) were used in this study (51 male and 51 female, 7-11 weeks old), as described by Araldi et al. (2015). The employed protocol was approved by the Ethics Committee in Animal Use of UNESP - Faculdade de Ciências e Letras de Assis (process No. 09/2011). This particular breed of mice was chosen because they do not sequester micronucleated erythrocytes, which is what occurs in rats and humans (Araldi et al., 2015), and this prevents false-negative results, as a consequence of spleen micronucleated cells. Mice were acclimated in the biotery of UNESP - Faculdade de Ciências e Letras de Assis for 5 days under the following conditions: $12-12 \mathrm{~h}$ light/dark cycle, 150 lux lighting, ambient temperature of $22^{\circ} \pm 2{ }^{\circ} \mathrm{C}$, and water and food ad libitum. Mice were divided into groups according to Table 1 . These groups allowed for the evaluation of the mutagenic potential of treatment with sibutramine alone for 7 or 15 consecutive days ( $\mathrm{N}=6$ for each) or treatment with sibutramine and $S$. maxima for 7 consecutive days $(\mathrm{N}=10)$. The negative control group was treated with $1 \mathrm{~mL} 0.9 \%$ saline by gavage. The positive control group was treated with $50 \mathrm{mg} / \mathrm{kg}$ of cyclophosphamide (Sigma-Aldrich, Germany) by intraperitoneal injection. The drugs were dissolved in $0.3 \mathrm{~mL}$ saline and administered by gavage daily, according to Table 1. All procedures were done according to Araldi et al. (2015). Mice were euthanized $48 \mathrm{~h}$ after the last gavage by cervical dislocation. Femurs were surgically removed and the epiphyses were cut off using sterile surgical scissors. Bone marrow was extracted by injecting $1 \mathrm{~mL}$ bovine fetal serum. Biological material was homogenized in Petri dishes and centrifuged at $400 \mathrm{~g}$ for $5 \mathrm{~min}$. The supernatant was discarded and the pellet was transferred to 2 slides, which were previously cleaned with $70 \%$ ethanol. Material was fixed with absolute methanol for 5 min and dried at room temperature for $2 \mathrm{~h}$. Slides were stained with 1:5 Gimesa-phosphate buffered saline (PBS), $\mathrm{pH}$ 6.0, and washed in $100 \%$ xylene. After drying, the slides were mounted with Entellan mounting media (Merck, Germany). A total of 1000 PCEs were analyzed per slide, totaling 2000 PCE per mouse, using a binocular microscope at a magnification of 1000X. The frequency of micronucleated PCEs (MNPCE) was analyzed. Statistical analyses were done based on the MNPCE frequency, using the Mann-Whitney test (to compare sibutramine treatment for 7 or 15 days) and the Kruskal-Wallis $\mathrm{H}$ test followed by the Dunn post-hoc test (to comparison all groups). All tests were done with $5 \%$ significance level using the BioEstat software (Ayres et al., 2007). Box plots were used to visualize the comparison of the different treatments.

\section{CBMNT}

Five milliliters peripheral blood was collected from 10 healthy individuals ( 5 men and 5 women, 18-25 years of age). These selected individuals were not taking pharmacological drugs, 
were non-smokers and did not ingest alcohol for at least one month before the blood was collected. The protocol of this test was done according to the 196/96 Resolution of Conselho Nacional de Saúde (CNS, Brazil) and was approved by the Ethics Committee in Research of UNESP Faculdade de Ciências e Letras de Assis (protocol No. 1233/2010). Peripheral blood was collect by venipuncture using the Vacutainer system with heparin. Biological material was immediately distributed in lymphocyte culture, as shown in Table 1. The mutagenic potential of $S$. maxima alone was not evaluated by the PCEMNT. The protocol of CBMNT was done according the technical recommendations proposed by Araldi et al. (2014) and Araldi et al. (2015). Briefly, $0.2 \mathrm{~mL}$ peripheral blood was transferred to a culture flask containing $5 \mathrm{~mL}$ RPMI 1640 media supplemented with $15 \%$ fetal bovine serum, $0.1 \mathrm{~mL}$ L-glutamine, and $0.1 \mathrm{~mL}$ phytohemagglutinin $\mathrm{A}(\mathrm{PHA})$. The material was incubated at $37^{\circ} \mathrm{C}$ for $8 \mathrm{~h}$, followed by the addition of drugs as shown in Table 1. After $44 \mathrm{~h}, 0.2$ $\mathrm{mL}$ cytochalasin $\mathrm{B}$ was added to block cytokinesis. After $72 \mathrm{~h}$, growth was halted with the addition of $0.5 \mathrm{~mL}$ methanol: acetic acid fixative $(3: 1 \mathrm{v} / \mathrm{v})$ for $5 \mathrm{~min}$ at room temperature. The material was centrifuged at $400 \mathrm{~g}$ and the supernatant was discarded. The pellet was homogenized with $5 \mathrm{~mL}$ fixative and centrifuged at $400 \mathrm{~g}$. The supernatant was discarded and the pellet transferred to slides, which were stained with 1:3 Giemsa-phosphate buffered saline, pH 6.8, for 8 min. After staining, coverslips were placed on slides with Entellan mounting media (Merck). The material was analyzed blindly under an Axiophot binocular microscope (Carl Zeiss, Germany) to observe the frequency of micronucleated-binucleated lymphocytes in a total of 1000 cells. Statistical analysis was performed using the Chi-squared and Kruskal-Wallis $\mathrm{H}$ tests, followed by a Dunn post-hoc test. The tests were done with a significance level of $5 \%$. All statistical tests were done using the BioEstat software (Ayres et al., 2007).

Table 1. Drug and dose administered in polychromatic erythrocyte micronucleus test (PCEMNT) in groups of 6 or 10 mice and cytokinesis-blocked micronucleus test (CBMNT) using peripheral blood of 10 individuals.

\begin{tabular}{lll}
\hline & PCMNT & CBMNT \\
\hline Groups & Drug and dose & Drug and dose \\
$\mathrm{C}+$ & Cyclophosphamide $50 \mathrm{mg} / \mathrm{kg}$ & Cyclophosphamide $50 \mu \mathrm{g} / \mathrm{mL}$ \\
$\mathrm{C}-$ & Saline $0.9 \%$ & \\
$\mathrm{Sb} 5$ & Sibutramine $5 \mathrm{mg} / \mathrm{kg}$ & Sibutramine $5 \mu \mathrm{g} / \mathrm{mL}$ \\
$\mathrm{Sb7}$ & Sibutramine $7 \mathrm{mg} / \mathrm{kg}$ & Sibutramine $7 \mu \mathrm{g} / \mathrm{mL}$ \\
$\mathrm{Sb} 10$ & Sibutramine $10 \mathrm{mg} / \mathrm{kg}$ & Sibutramine $10 \mu \mathrm{g} / \mathrm{mL}$ \\
$\mathrm{Sb} 15$ & Sibutramine $15 \mathrm{mg} / \mathrm{kg}$ & Sibutramine $15 \mu \mathrm{g} / \mathrm{mL}$ \\
$\mathrm{Sb} 20$ & Sibutramine $20 \mathrm{mg} / \mathrm{kg}$ & Sibutramine $20 \mu \mathrm{g} / \mathrm{mL}$ \\
$\mathrm{Groups}$ & Drug and dose & Drug and dose \\
$\mathrm{C}+$ & Cyclophosphamide $50 \mathrm{mg} / \mathrm{kg}$ & Cyclophosphamide $50 \mu \mathrm{gg} / \mathrm{mL}$ \\
$\mathrm{C}-$ & Saline $0.9 \%$ & \\
$\mathrm{Sb7}+\mathrm{Sm} 150$ & Sibutramine $7 \mathrm{mg} / \mathrm{kg}+$ S. maxima $150 \mathrm{mg} / \mathrm{kg}$ & Sibutramine $7 \mu \mathrm{g} / \mathrm{mL}+$ S. maxima $150 \mu \mathrm{\mu g} / \mathrm{mL}$ \\
$\mathrm{Sb} 7+\mathrm{Sm} 300$ & Sibutramine $7 \mathrm{mg} / \mathrm{kg}+$ S. maxima $300 \mathrm{mg} / \mathrm{kg}$ & Sibutramine $7 \mu \mathrm{g} / \mathrm{mL}+$ S. maxima $300 \mu \mathrm{gg} / \mathrm{mL}$ \\
$\mathrm{Sb} 10+\mathrm{Sm} 150$ & Sibutramine $15 \mathrm{mg} / \mathrm{kg}+$ S. maxima $150 \mathrm{mg} / \mathrm{kg}$ & Sibutramine $15 \mu \mathrm{mL}+$ S. maxima $150 \mu \mathrm{gg} / \mathrm{mL}$ \\
$\mathrm{Sb} 10+\mathrm{Sm} 300$ & Sibutramine $15 \mathrm{mg} / \mathrm{kg}+$ S. maxima $300 \mathrm{mg} / \mathrm{kg}$ & Sibutramine $15 \mu \mathrm{g} / \mathrm{mL}+$ S. maxima $300 \mu \mathrm{gg} / \mathrm{mL}$ \\
\hline
\end{tabular}

*Two groups, one treated with either drug for 7 consecutive days and other for 15 consecutive days were analyzed by PCMNT. ${ }^{1}$ Group of 6 mice. ${ }^{2}$ Group of 10 mice. $\mathrm{Sb}=$ sibutramine; $\mathrm{Sm}=$ Spirulina maxima; $\mathrm{C}+=$ positive control; $\mathrm{C}-=$ negative control.

\section{RESULTS}

\section{PCEMNT results for treatment with sibutramine alone}

The frequency of MNPCEs was examined in mice treated with 4 different doses of 
sibutramine for 7 or 15 days (Table 2) and the Mann-Whitney test was done to compare the effect of treatment time. There were no differences between treatment for 7 or 15 days with cyclophosphamide or saline (positive and negative control, respectively), as expected (Table 3). However, there were significant statistical differences between all groups (Table 3 ). This result suggests the time-dependent mutagenic potential of sibutramine. After 7 days of treatment, doses of 7 and $15 \mathrm{mg} / \mathrm{kg}$ showed the highest values for maximum number of micronuclei (Figure 1A), whereas after 15 days of treatment, the dose of $10 \mathrm{mg} / \mathrm{kg}$ revealed the most elevated mutagenic potential (Figure 1B). Based on these results, we chose to examine the effect of sibutramine doses of 7 and $15 \mathrm{mg} / \mathrm{kg}$ with simultaneous treatment with S. maxima. These doses were chosen due to their frequent use in Brazil, where the abuse of sibutramine is commonly observed. Consumption of $15 \mathrm{mg} / \mathrm{kg}$ sibutramine for treatment of obesity is authorized by ANVISA in Brazil.

Table 2. Frequency of micronucleated polychromatic erythrocytes observed in a group of 6 mice treated with sibutramine at doses of $5,7,10,15$, or $20 \mathrm{mg} / \mathrm{kg}$ for 7 or 15 consecutive days.

\begin{tabular}{|c|c|c|c|c|c|c|c|}
\hline \multirow[b]{2}{*}{ Group ${ }^{1}$} & \multicolumn{7}{|c|}{ Animal } \\
\hline & 1 & 2 & 3 & 4 & 5 & 6 & Total \\
\hline $\mathrm{C}+$ & 6 & 8 & 7 & 8 & 6 & 9 & 44 \\
\hline C- & 1 & 1 & 2 & 1 & 2 & 2 & 9 \\
\hline $\mathrm{Sb} 5$ & 5 & 4 & 3 & 6 & 5 & 6 & 29 \\
\hline $\mathrm{Sb} 7$ & 8 & 9 & 12 & 10 & 7 & 8 & 54 \\
\hline Sb10 & 7 & 8 & 6 & 8 & 8 & 7 & 44 \\
\hline Sb15 & 5 & 5 & 6 & 7 & 7 & 8 & 38 \\
\hline Sb20 & 7 & 5 & 5 & 4 & 5 & 6 & 32 \\
\hline Group 2 & 1 & 2 & 3 & 4 & 5 & 6 & Total \\
\hline $\mathrm{C}+$ & 6 & 8 & 7 & 8 & 6 & 9 & 44 \\
\hline C- & 1 & 1 & 2 & 1 & 1 & 2 & 8 \\
\hline $\mathrm{Sb} 5$ & 9 & 10 & 11 & 13 & 12 & 12 & 67 \\
\hline $\mathrm{Sb} 7$ & 7 & 8 & 6 & 5 & 7 & 7 & 40 \\
\hline Sb10 & 20 & 23 & 21 & 20 & 22 & 24 & 130 \\
\hline Sb15 & 12 & 11 & 10 & 9 & 13 & 10 & 65 \\
\hline Sb20 & 8 & 7 & 6 & 8 & 9 & 9 & 47 \\
\hline
\end{tabular}

${ }^{1}$ Group treated for 7 consecutive days. ${ }^{2}$ Group treated for 15 consecutive days. $\mathrm{Sb}=$ sibutramine; $\mathrm{C}+=$ positive control; $\mathrm{C}-=$ negative control.

Table 3. Mann-Whitney test comparing the frequency of micronucleated polychromatic erythrocytes observed after treatment with different doses of sibutramine $(\mathrm{mg} / \mathrm{kg})$ for 7 or 15 days.

\begin{tabular}{lrcr}
\hline Groups & $U$ & $Z(U)$ & $P$ value \\
\hline C+ & 18.0 & 0.0000 & 0.5000 \\
C- & 15.0 & 0.4804 & 0.3155 \\
Sb5 & 0.0 & 2.8823 & 0.0020 \\
Sb7 & 3.5 & 2.3219 & 0.0101 \\
Sb10 & 0.0 & 2.8230 & 0.0020 \\
Sb15 & 0.0 & 2.8823 & 0.0020 \\
Sb20 & 2.0 & 2.5624 & 0.0052 \\
\hline
\end{tabular}

$\mathrm{Sb}=$ sibutramine; $\mathrm{C}+=$ positive control; $\mathrm{C}-$ = negative control; $\mathrm{U}$ - Mann-Whitney value and $\mathrm{Z}(\mathrm{U})$ - sum-of-ranks of $\mathrm{U}$ values.

\section{PCEMNT results for treatment with sibutramine and S. maxima}

The Kruskal-Wallis test was done to compare frequency of micronuclei observed per mouse in different groups (Table 4). There were statistically significant differences found between 
the different groups of mice $(H=39.7529$ and $P=0)$. The Dunn test (Table 5) indicated an elevated frequency of micronuclei in the positive control in relation to the negative control (Table 6). The groups treated with sibutramine alone $(7$ or $15 \mathrm{mg} / \mathrm{kg}$ ) or with $15 \mathrm{mg} / \mathrm{kg}$ sibutramine and 150 $\mathrm{mg} / \mathrm{kg}$ S. maxima revealed a mutagenic potential statistically equivalent to the positive control (Table 6). However, the groups treated with $7 \mathrm{mg} / \mathrm{kg}$ sibutramine $+150 \mathrm{mg} / \mathrm{kg} \mathrm{S}$. maxima, $7 \mathrm{mg} /$ $\mathrm{kg}$ sibutramine $+300 \mathrm{mg} / \mathrm{kg} \mathrm{S}$. maxima, or $15 \mathrm{mg} / \mathrm{kg}$ sibutramine $+300 \mathrm{mg} / \mathrm{kg} \mathrm{S}$. maxima showed an intermediate number of micronuclei in relation to the positive and negative controls (Table 6). These data suggest that simultaneous treatment with $S$. maxima can reduce the mutagenic potential of sibutramine. A reduction in frequency of micronuclei was observed in groups treated with a minimum dose of sibutramine $(7 \mathrm{mg} / \mathrm{kg})$ with $S$. maxima and a maximum dose of sibutramine $(15 \mathrm{mg} / \mathrm{kg}$ ) with a maximum dose of $S$. maxima $(300 \mathrm{mg} / \mathrm{kg})$. However, these groups showed intermediated values of micronuclei, indicating that $S$. maxima, in these concentrations, is not enough to avoid DNA damages induced by sibutramine.
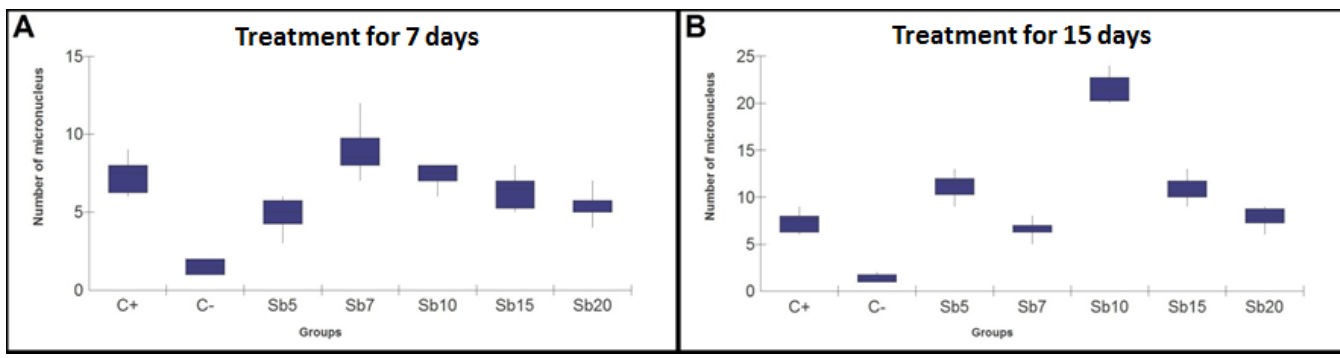

Figure 1. Box plot comparing the maximum and minimum number of micronuclei observed in groups of 6 mice treated with sibutramine $(5,7,10,15$, or $20 \mathrm{mg} / \mathrm{kg})$ for 7 (A) or 15 (B) consecutive days. $C_{+}=$positive control; $C_{-}=$negative control; $\mathrm{Sb}=$ sibutramine.

Table 4. Frequency of micronucleated polychromatic erythrocytes observed in a group of 10 mice treated for 7 days with sibutramine $(\mathrm{Sb})$ and Spirulina maxima $(\mathrm{Sm})$.

\begin{tabular}{|c|c|c|c|c|c|c|c|c|c|c|c|}
\hline \multirow[b]{2}{*}{ Groups } & \multicolumn{11}{|c|}{ Animal } \\
\hline & 1 & 2 & 3 & 4 & 5 & 6 & 7 & 8 & 9 & 10 & Total \\
\hline $\mathrm{C}+$ & 7 & 6 & 17 & 7 & 3 & 21 & 6 & 13 & 12 & 8 & 100 \\
\hline C- & 4 & 3 & 3 & 0 & 1 & 0 & 2 & 1 & 0 & 3 & 17 \\
\hline Sb5 + Sm150 & 5 & 6 & 6 & 7 & 7 & 7 & 3 & 4 & 6 & 5 & 56 \\
\hline $\mathrm{Sb} 7+\mathrm{Sm} 300$ & 6 & 5 & 5 & 6 & 7 & 5 & 2 & 4 & 5 & 0 & 45 \\
\hline Sb10 + Sm150 & 5 & 6 & 6 & 7 & 6 & 6 & 7 & 7 & 5 & 6 & 61 \\
\hline $\mathrm{Sb} 10+\mathrm{Sm} 300$ & 8 & 4 & 6 & 7 & 7 & 5 & 4 & 3 & 5 & 0 & 49 \\
\hline
\end{tabular}

$\mathrm{C}+=$ positive control; $\mathrm{C}-$ = negative control.

\section{CBMNT results for treatment with sibutramine and S. maxima}

The Kruskal-Wallis $\mathrm{H}$ test was done to compare the frequency of binucleated lymphocytes with micronuclei in all groups (Table 7) and a statistically significant difference was found among the groups $(\mathrm{H}=39.6964$ and $\mathrm{P}=0$ ). The Dunn test (Table 8) showed differences between the positive and negative controls (Table 9), as expected. This data reinforces the results observed with the PCEMNT test. The Dunn test also showed that the $7 \mathrm{mg} / \mathrm{kg}$ sibutramine $+300 \mathrm{mg} / \mathrm{kg} \mathrm{S}$. maxima and $15 \mathrm{mg} / \mathrm{kg}$ sibutramine $+150 \mathrm{mg} / \mathrm{kg} \mathrm{S}$. maxima groups showed the highest reduction in mutagenic potential (Figure 2), which is slightly different from the data obtained with the PCEMNT test. 
Table 5. Dunn post-hoc test comparing the frequency of micronuclei observed in different groups (control and experimental) of mice.

\begin{tabular}{|c|c|c|c|}
\hline Comparison between groups & Post differences & $Z$ calculated & $P$ value \\
\hline $\mathrm{C}+$ and $\mathrm{C}-$ & 45.7000 & 4.8827 & $<0.05$ \\
\hline $\mathrm{C}+$ and $\mathrm{Sb} 7$ & 9.2000 & 0.8513 & ns \\
\hline $\mathrm{C}+$ and $\mathrm{Sb} 15$ & 10.5500 & 0.9762 & ns \\
\hline $\mathrm{C}+$ and $\mathrm{Sb} 7+\mathrm{Sm} 150$ & 18.0500 & 1.9285 & ns \\
\hline $\mathrm{C}+$ and $\mathrm{Sb} 7+\mathrm{Sm} 300$ & 27.5000 & 2.9382 & ns \\
\hline $\mathrm{C}+$ and $\mathrm{Sb} 15+\mathrm{Sm} 150$ & 13.2000 & 1.4103 & ns \\
\hline $\mathrm{C}+$ and $\mathrm{Sb} 15+\mathrm{Sm} 300$ & 22.9000 & 2.4467 & ns \\
\hline $\mathrm{C}-$ and Sb7 & 54.9000 & 5.0799 & $<0.05$ \\
\hline C- and Sb15 & 35.1500 & 3.2524 & $<0.05$ \\
\hline C- and Sb7 + Sm150 & 27.6500 & 2.9542 & ns \\
\hline $\mathrm{C}-$ and Sb7 + Sm300 & 18.2000 & 1.9446 & ns \\
\hline C- and Sb15 + Sm150 & 32.5000 & 3.4724 & $<0.05$ \\
\hline $\mathrm{C}$ - and Sb7 + Sm300 & 22.8000 & 2.4360 & ns \\
\hline $\mathrm{Sb} 7$ and $\mathrm{Sb} 15$ & 19.7500 & 1.6345 & ns \\
\hline $\mathrm{Sb} 7$ and $\mathrm{Sb} 7+\mathrm{Sm} 150$ & 27.2500 & 2.5214 & ns \\
\hline $\mathrm{Sb} 7$ and $\mathrm{Sb} 7+\mathrm{Sm} 300$ & 36.7000 & 3.3958 & $<0.05$ \\
\hline $\mathrm{Sb} 7$ and $\mathrm{Sb} 15+\mathrm{Sm} 150$ & 22.4000 & 2.0727 & ns \\
\hline $\mathrm{Sb} 7$ and $\mathrm{Sb} 15+\mathrm{Sm} 300$ & 32.1000 & 2.9702 & ns \\
\hline $\mathrm{Sb} 15$ and $\mathrm{Sb} 7+\mathrm{Sm} 150$ & 7.5000 & 0.6940 & ns \\
\hline $\mathrm{Sb} 15$ and $\mathrm{Sb} 7+\mathrm{Sm} 300$ & 16.9500 & 1.5684 & ns \\
\hline $\mathrm{Sb} 15$ and $\mathrm{Sb} 15+\mathrm{Sm} 150$ & 2.6500 & 0.2452 & ns \\
\hline Sb15 and Sb15 and Sm300 & 12.3500 & 1.1427 & ns \\
\hline $\mathrm{Sb} 7+\mathrm{Sm} 150$ and $\mathrm{Sb} 7+\mathrm{Sm} 300$ & 9.4500 & 1.0097 & ns \\
\hline $\mathrm{Sb} 7+\mathrm{Sm} 150$ and Sb15 + Sm150 & 4.8500 & 0.5182 & ns \\
\hline $\mathrm{Sb} 7+\mathrm{Sm} 150$ and $\mathrm{Sb} 15+\mathrm{Sm} 300$ & 4.8500 & 0.5182 & ns \\
\hline $\mathrm{Sb} 7+\mathrm{Sm} 300$ and $\mathrm{Sb} 15+\mathrm{Sm} 150$ & 14.3000 & 1.5279 & ns \\
\hline $\mathrm{Sb} 7+\mathrm{Sm} 300$ and $\mathrm{Sb} 15$ and $\mathrm{Sm} 300$ & 4.6000 & 0.4915 & ns \\
\hline Sb15 + Sm 150 and $S b 15$ and $S m 300$ & 9.7000 & 1.0364 & ns \\
\hline
\end{tabular}

$\mathrm{C}+$ = positive control; $\mathrm{C}-$ = negative control; $\mathrm{Sb}=$ sibutramine; $\mathrm{Sm}=$ Spirulina maxima; $\mathrm{ns}=$ not significant

Table 6. Statistical comparison of the frequency of micronuclei in different treatment groups based on the Dunn test.

\begin{tabular}{|c|c|c|c|c|c|c|c|c|}
\hline \multirow[b]{2}{*}{ Animal } & \multicolumn{8}{|c|}{ Groups } \\
\hline & $\overline{C+}$ & C- & Sb7 & Sb15 & $\mathrm{Sb} 7+\mathrm{Sm} 150$ & $\mathrm{Sb} 7+\mathrm{Sm} 300$ & $\mathrm{Sb} 15+\mathrm{Sm} 150$ & $\mathrm{Sb} 15+\mathrm{Sm} 300$ \\
\hline 1 & $7^{\mathrm{a}^{*}}$ & $4^{b}$ & $8^{a}$ & $5^{a}$ & $5^{a, b}$ & $6^{a, b}$ & $5^{a}$ & $8^{a, b}$ \\
\hline 2 & $6^{a}$ & $3^{\mathrm{b}}$ & $9^{a}$ & $5^{a}$ & $6^{a, b}$ & $5^{a, b}$ & $6^{a}$ & $4^{a, b}$ \\
\hline 3 & $17^{\mathrm{a}}$ & $3^{\mathrm{b}}$ & $12^{a}$ & $6^{a}$ & $6^{\mathrm{a}, \mathrm{b}}$ & $5^{a, b}$ & $6^{a}$ & $6^{a, b}$ \\
\hline 4 & $7^{a}$ & $0^{\mathrm{b}}$ & $10^{\mathrm{a}}$ & $7^{a}$ & $7^{\mathrm{a}, \mathrm{b}}$ & $6^{\mathrm{a}, \mathrm{b}}$ & $7^{a}$ & $7^{a, b}$ \\
\hline 5 & $3^{a}$ & $1^{\mathrm{b}}$ & $7^{\mathrm{a}}$ & $7^{a}$ & $7^{a, b}$ & $7^{\mathrm{a}, \mathrm{b}}$ & $6^{a}$ & $7^{\mathrm{a}, \mathrm{b}}$ \\
\hline 6 & $21^{a}$ & $0^{\mathrm{b}}$ & $8^{a}$ & $8^{a}$ & $7^{a, b}$ & $5^{a, b}$ & $6^{a}$ & $5^{a, b}$ \\
\hline 7 & $6^{a}$ & $2^{\mathrm{b}}$ & - & - & $3^{a, b}$ & $2^{a, b}$ & $7^{a}$ & $4^{\mathrm{a}, \mathrm{b}}$ \\
\hline 8 & $13^{a}$ & $1^{\mathrm{b}}$ & - & - & $4^{a, b}$ & $4^{\mathrm{a}, \mathrm{b}}$ & $7^{a}$ & $3^{a, b}$ \\
\hline 9 & $12^{\mathrm{a}}$ & $0^{\mathrm{b}}$ & - & - & $6^{a, b}$ & $5^{\mathrm{a}, \mathrm{b}}$ & $5^{\mathrm{a}}$ & $5^{\mathrm{a}, \mathrm{b}}$ \\
\hline 10 & $8^{a}$ & $3^{b}$ & - & - & $5^{a, b}$ & $0^{a, b}$ & $6^{a}$ & $0^{a, b}$ \\
\hline
\end{tabular}

$\mathrm{C}+=$ positive control; $\mathrm{C}-=$ negative control; $\mathrm{Sb}=$ sibutramine; $\mathrm{Sm}=$ Spirulina maxima. ${ }^{*}$ Numbers followed by equal letter indicate absence of statistical significant differences.

Table 7. Frequency of micronuclei in binucleated lymphocytes in 10 samples (groups 1-10) of human peripheral blood treated for 7 days with varying doses of sibutramine $(\mathrm{Sb})$ and Spirulina maxima $(\mathrm{Sm})$.

\begin{tabular}{|c|c|c|c|c|c|c|c|c|c|c|c|}
\hline Group & 1 & 2 & 3 & 4 & 5 & 6 & 7 & 8 & 9 & 10 & Total \\
\hline $\mathrm{C}+$ & 10 & 15 & 17 & 20 & 11 & 12 & 24 & 17 & 30 & 11 & 167 \\
\hline C- & 5 & 5 & 4 & 8 & 4 & 8 & 9 & 4 & 15 & 3 & 65 \\
\hline $\mathrm{Sb} 7$ & 13 & 18 & 16 & 17 & 15 & 13 & 16 & 14 & 13 & 15 & 150 \\
\hline Sb15 & 15 & 20 & 18 & 20 & 15 & 10 & 17 & 19 & 16 & 18 & 168 \\
\hline $\mathrm{Sb} 7+\mathrm{Sm} 150$ & 8 & 8 & 12 & 8 & 12 & 7 & 14 & 14 & 15 & 13 & 101 \\
\hline $\mathrm{Sb} 7+\mathrm{Sb} 300$ & 5 & 8 & 8 & 12 & 13 & 9 & 13 & 13 & 14 & 12 & 107 \\
\hline Sb15 + Sm150 & 7 & 8 & 7 & 11 & 15 & 7 & 13 & 14 & 13 & 8 & 103 \\
\hline $\mathrm{Sb} 15+\mathrm{Sm} 300$ & 8 & 9 & 13 & 12 & 14 & 10 & 16 & 11 & 12 & 12 & 117 \\
\hline
\end{tabular}

$\mathrm{C}+=$ positive control; $\mathrm{C}-$ = negative control. 
Table 8. Dunn post-hoc test comparing the frequency of micronuclei observed in human binucleated lymphocytes in different groups (control and experimental).

\begin{tabular}{|c|c|c|c|}
\hline Comparison between groups & Post differences & $Z$ calculated & $P$ value \\
\hline $\mathrm{C}+$ and $\mathrm{C}-$ & 41.7500 & 4.0174 & $<0.05$ \\
\hline $\mathrm{C}+$ and Sb7 & 2.35000 & 0.2261 & ns \\
\hline $\mathrm{C}+$ and $\mathrm{Sb} 15$ & 10.0000 & 0.9623 & ns \\
\hline $\mathrm{C}+$ and $\mathrm{Sb} 7+\mathrm{Sm} 150$ & 21.6000 & 2.0785 & ns \\
\hline $\mathrm{C}+$ and $\mathrm{Sb} 7+\mathrm{Sm} 300$ & 23.6000 & 2.2709 & ns \\
\hline $\mathrm{C}+$ and $\mathrm{Sb} 15+\mathrm{Sm} 150$ & 26.3000 & 2.5307 & ns \\
\hline $\mathrm{C}+$ and $\mathrm{Sb} 15+\mathrm{Sm} 300$ & 19.1000 & 1.8379 & ns \\
\hline $\mathrm{C}-$ and $\mathrm{Sb} 7$ & 44.1000 & 4.2435 & $<0.05$ \\
\hline C- and Sb15 & 51.7500 & 4.9796 & $<0.05$ \\
\hline C- and Sb7 + Sm150 & 20.1500 & 1.9389 & ns \\
\hline $\mathrm{C}-$ and Sb7 + Sm300 & 18.1500 & 1.7465 & ns \\
\hline C- and Sb15 + Sm150 & 15.4500 & 1.4867 & ns \\
\hline C- and Sb7 + Sm300 & 22.6500 & 2.1795 & ns \\
\hline $\mathrm{Sb} 7$ and $\mathrm{Sb} 15$ & 7.65000 & 0.7361 & ns \\
\hline $\mathrm{Sb} 7$ and $\mathrm{Sb} 7+\mathrm{Sm} 150$ & 23.9500 & 2.3046 & ns \\
\hline $\mathrm{Sb} 7$ and $\mathrm{Sb} 7+\mathrm{Sm} 300$ & 25.9500 & 2.4970 & ns \\
\hline $\mathrm{Sb} 7$ and $\mathrm{Sb} 15+\mathrm{Sm} 150$ & 28.6500 & 2.7568 & ns \\
\hline $\mathrm{Sb} 7$ and $\mathrm{Sb} 15+\mathrm{Sm} 300$ & 21.4500 & 2.0640 & ns \\
\hline $\mathrm{Sb} 15$ and $\mathrm{Sb} 7+\mathrm{Sm} 150$ & 31.6000 & 3.0407 & ns \\
\hline $\mathrm{Sb} 15$ and $\mathrm{Sb} 7+\mathrm{Sm} 300$ & 33.6000 & 3.2332 & $<0.05$ \\
\hline $\mathrm{Sb} 15$ and $\mathrm{Sb} 15+\mathrm{Sm} 150$ & 36.3000 & 3.4930 & $<0.05$ \\
\hline $\mathrm{Sb} 15$ and $\mathrm{Sb} 15$ and $\mathrm{Sm} 300$ & 29.1000 & 2.8001 & ns \\
\hline $\mathrm{Sb} 7+\mathrm{Sm} 150$ and $\mathrm{Sb} 7+\mathrm{Sm} 300$ & 2.00000 & 0.1925 & ns \\
\hline $\mathrm{Sb} 7+\mathrm{Sm} 150$ and $\mathrm{Sb} 15+\mathrm{Sm} 150$ & 4.70000 & 0.4523 & ns \\
\hline $\mathrm{Sb} 7+\mathrm{Sm} 150$ and $\mathrm{Sb} 15+\mathrm{Sm} 300$ & 2.50000 & 0.2406 & ns \\
\hline $\mathrm{Sb} 7+\mathrm{Sm} 300$ and $\mathrm{Sb} 15+\mathrm{Sm} 150$ & 2.70000 & 0.2598 & ns \\
\hline $\mathrm{Sb} 7+\mathrm{Sm} 300$ and $\mathrm{Sb} 15$ and $\mathrm{Sm} 300$ & 4.50000 & 0.4330 & ns \\
\hline $\mathrm{Sb} 15+\mathrm{Sm} 150$ and $\mathrm{Sb} 15$ and $\mathrm{Sm} 300$ & 7.20000 & 4.0174 & ns \\
\hline
\end{tabular}

ns = not significant; $\mathrm{C}+=$ positive control; $\mathrm{C}-$ = negative control; Sb = sibutramine; Sm = Spirulina maxima.

Table 9. Statistical comparison of the frequency of micronuclei observed in binucleated lymphocytes based on the Dunn test.

\begin{tabular}{|c|c|c|c|c|c|c|c|c|}
\hline \multirow[b]{2}{*}{ Animal } & \multicolumn{8}{|c|}{ Groups } \\
\hline & $\mathrm{C}+$ & C- & $\mathrm{Sb} 7$ & $\mathrm{Sb} 15$ & $\mathrm{Sb} 7+\mathrm{Sm} 150$ & $\mathrm{Sb} 7+\mathrm{Sm} 300$ & $\mathrm{Sb} 15+\mathrm{Sm} 150$ & $\mathrm{Sb} 15+\mathrm{Sm} 300$ \\
\hline 1 & $10^{\mathrm{a}}$ & $5^{\mathrm{b}}$ & $13^{a}$ & $15^{\mathrm{a}, \mathrm{b}}$ & $8^{a, b}$ & $5^{\mathrm{a}, \mathrm{b}, \mathrm{c}}$ & $7^{\mathrm{a}, \mathrm{b}, \mathrm{c}}$ & $8^{\mathrm{a}, \mathrm{b}}$ \\
\hline 2 & $15^{\mathrm{a}}$ & $5^{b}$ & $18^{a}$ & $20^{a, b}$ & $8^{a, b}$ & $8^{\mathrm{a}, \mathrm{b}, \mathrm{b}, \mathrm{c}}$ & $8^{a, b, c}$ & $9^{\mathrm{a}, \mathrm{b}}$ \\
\hline 3 & $17^{a}$ & $4^{b}$ & $16^{a}$ & $18^{a, b}$ & $12^{a, b}$ & $8^{a, b, c}$ & $7^{a, b, c}$ & $13^{\mathrm{a}, \mathrm{b}}$ \\
\hline 4 & $20^{a}$ & $8^{\mathrm{b}}$ & $17^{a}$ & $20^{a, b}$ & $8^{a, b}$ & $12^{a, b, c}$ & $11^{\mathrm{a}, \mathrm{b}, \mathrm{c}}$ & $12^{a, b}$ \\
\hline 5 & $11^{\mathrm{a}}$ & $4^{b}$ & $15^{a}$ & $15^{\mathrm{a}, \mathrm{b}}$ & $12^{a, b}$ & $13^{a, b, c}$ & $15^{a, b, c}$ & $14^{\mathrm{a}, \mathrm{b}}$ \\
\hline 6 & $12^{\mathrm{a}}$ & $8^{\mathrm{b}}$ & $13^{a}$ & $10^{\mathrm{a}, \mathrm{b}}$ & $7^{\mathrm{a}, \mathrm{b}}$ & $9^{a, b, c}$ & $7^{\mathrm{a}, \mathrm{b}, \mathrm{c}}$ & $10^{a, b}$ \\
\hline 7 & $24^{a}$ & $9^{b}$ & $16^{a}$ & $17^{a, b}$ & $14^{\mathrm{a}, \mathrm{b}}$ & $13^{a, b, c}$ & $13^{a, b, c}$ & $16^{a, b}$ \\
\hline 8 & $17^{a}$ & $4^{b}$ & $14^{\mathrm{a}}$ & $19^{a, b}$ & $14^{\mathrm{a}, \mathrm{b}}$ & $13^{a, b, c}$ & $14^{a, b, c}$ & $11^{\mathrm{a}, \mathrm{b}}$ \\
\hline 9 & $30^{\mathrm{a}}$ & $15^{\mathrm{b}}$ & $13^{a}$ & $16^{\mathrm{a}, \mathrm{b}}$ & $15^{\mathrm{a}, \mathrm{b}}$ & $14^{\mathrm{a}, \mathrm{b}, \mathrm{c}}$ & $13^{a, b, c}$ & $12^{\mathrm{a}, \mathrm{b}}$ \\
\hline 10 & $11^{a}$ & $3^{\mathrm{b}}$ & $15^{a}$ & $18^{\mathrm{a}, \mathrm{b}}$ & $13^{a, b}$ & $12^{a, b, c}$ & $8^{a, b, c}$ & $12^{\mathrm{a}, \mathrm{b}}$ \\
\hline
\end{tabular}

$\mathrm{C}+=$ positive control; $\mathrm{C}-=$ negative control; $\mathrm{Sb}=$ sibutramine; $\mathrm{Sm}=$ Spirulina maxima. ${ }^{*}$ Numbers followed by equal letters indicate absence of significant statistical differences.

\section{DISCUSSION}

Mutagenic tests are required by regulatory international agencies such as the FDA, EMA and ANVISA. Among the different tests, the PCEMNT and CBMNT are common as part of the battery of tests required for these agencies (Fenech, 2000, 2011; Araldi et al., 2014, 2015). This is because these techniques are simple, versatile, low cost and quick to perform. Moreover, these combined methods allow the detection of DNA damage (mutations), which is the first step of carcinogenesis. 


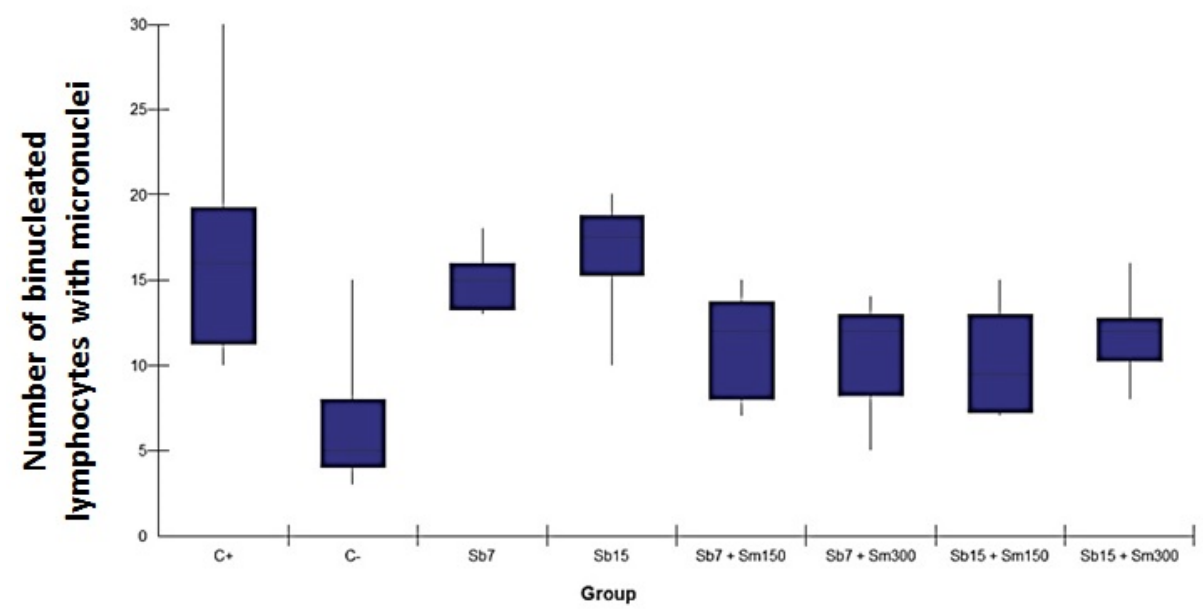

Figure 2. Box plot comparing the maximum and minimum number of micronuclei observed in binucleated lymphocytes from 10 samples of human peripheral blood after varying treatments of sibutramine (Sb) and/or Spirulina maxima (Sm). $\mathrm{C}_{+}=$positive control; $\mathrm{C}-=$ negative control.

Genomic instabilities are a hallmark of cancer (Fenech 2000; Araldi et al. 2015) and, for this reason, determining the mutagenic potential of a drug is crucial to introducing it into market. Furthermore, it is known that mutagenic risk is directly correlated with drug exposure time. The evaluation of the mutagenic potential of sibutramine is necessary because the drug is chronically used for weight loss and maintenance. Studies have shown that weight gain and obesity are associated with cancer; this association occurs because obesity contributes to chronic inflammation, promoting release of cytokines. Inflammation is another hallmark of cancer (Hanahan and Weinberg, 2011; Martinez-Outschoorn, et al., 2013), contributing to cancer initiation and progression. Thus, antiobesity therapy may promote weight loss without induction of mutagenesis, once obese patients already have a predisposition to develop cancer. However, Silva et al. (2010) reported that doses of 10,15 or $20 \mathrm{mg} / \mathrm{kg}$ sibutramine, administered by intraperitoneal injection in Swiss mice, induce DNA damage. This study verified that these doses of sibutramine are genotoxic, increasing the frequency of micronuclei and DNA fragmentation, which were observed by PCEMNT and CA, respectively. In this sense, our results are in accordance to Silva et al. (2010). Sibutramine, in doses of $5,7,10$ or $15 \mathrm{mg} / \mathrm{kg}$, promoted an increased frequency of micronuclei in PCE. No statistical differences were observed between the different doses and similar results were described in the literature. Silva et al. (Silva et al. 2010) did not show statistical differences between groups treated with 10 or $20 \mathrm{mg} / \mathrm{kg}$ sibutramine, which indicates the absence of dose dependence. However, the Mann-Whitney test indicated time-dependent genotoxicity, not demonstrated up to date. Sibutramine is frequently used for long periods of time, often exceeding 2 years, for weight maintenance so longterm treatment confers a high mutagenic risk for patients. In this study, sibutramine was administered orally to the mice and our data suggest that the drug has the same mutagenic effect independent of the method of administration. Sibutramine is demethylated in hepatocytes by cytochrome P 450 (CYP34A) to M1 and M2 amines, pharmacology activities (Luque and Rey, 2002). These amines inhibit the reuptake of 5-hydroxytryptamine (5-HT) and norepinephrine, promoting the activation of $\alpha$ - and $\beta$-adrenoceptors (Luque and Rey, 2002). Due to increased serotonergic and noradrenergic activity, sibutramine reduces food intake, which is responsible for weight loss (Luque and Rey, 2002). 
Although sibutramine did not show mutagenic activity in previous in vitro assays in mice (Snyder and Green, 2001), it is known that M1 and M2 metabolites have divergent effects in terms of mutagenic activity in an Ames test (Brambilla and Martelli, 2009). The genotoxic potential of sibutramine was also verified in mice in vivo (Silva et al., 2010), where low doses (5 and $7 \mathrm{mg} / \mathrm{kg}$ ) of sibutramine were shown to induce DNA damage. Due to the fact that few anti-obesity drugs are available on the market and the efficacy of sibutramine in weight loss and maintenance, we examined the effect of simultaneous delivery of sibutramine with the antioxidant-producing S. maxima. This was done to verify if the antioxidant components of $S$. maxima could reduce the genotoxicity of sibutramine. Both in vivo (PCEMNT) and in vitro (CBMNT) tests using 2 different models (mouse and human, respectively) showed that $S$. maxima is not able to reduce the mutagenic potential of sibutramine. Although groups treated with both sibutramine and S. maxima showed an intermediate micronuclei frequency in both PCEMNT and CBMNT, all groups had a number of micronucleated cells that was statistically similar to the groups treated with cyclophosphamide (positive control). These data suggest that the mild reduction in genotoxicity by S. maxima is not sufficient to improve the negative side effects of sibutramine.

The mutagenic potential of sibutramine is a consequence of the action of the drug. Sibutramine stimulates $\beta 3$-adrenergic receptors, increasing metabolic rate (Luque and Rey, 2002), which increases glucose consumption by the glycolytic pathway. Activation of glycolysis promotes an increase in cellular oxygen consumption (Luque and Rey, 2002), producing reactive oxygen species (ROS) (Luque and Rey, 2002). ROS are a product of aerobic metabolism (Schieber and Chandel, 2014), being the result of the partial reduction of oxygen (Reczek and Chandel, 2015). Mitochondria are the main source of ROS (Bleier et al., 2015), and superoxide anions, produced by complex III of the electron transport chain, are released into the intermembrane space (Bleier et al., 2015; Reczek and Chandel, 2015). Enrichment of superoxide anions can occur in the cytosol (Reczek and Chandel, 2015), where they are converted to hydrogen peroxide by dismutase superoxide (SOD1). Hydrogen peroxide mediates the oxidation of cysteine residues in proteins (Schieber and Chandel, 2014). Cysteines are present as thiolate anions (Cys-S) at physiological $\mathrm{pH}$ so they are susceptible to oxidation upon which they become protonated (Cys-SH) (Schieber and Chandel, 2014). Thus, hydrogen peroxide oxidizes the thiolate anion to the sulfenic form (Cys$\mathrm{SOH}$ ), causing allosteric changes in proteins that can modify their function irreversibly (Schieber and Chandel, 2014). This pathway can interfere in intercellular protein cascades, which can induce DNA damage by multiple mechanisms, such as mitotic stress. Thus, more studies are required to better understand the mutagenic mechanisms associated with sibutramine. Futures studies could verify if mutagenic potential is associated with M1 and M2 metabolites or ROS production as a consequence of metabolic stimulation.

Simultaneous delivery of $S$. maxima with sibutramine did not show a significant reduction in genotoxicity. Although the cyanobacterium is described as an antioxidant and anti-mutagenic due the presence of alfa-tocopherol and beta-carotene (Araldi et al., 2014), it was not able to significantly reduce the frequency of micronuclei. Genotoxicity conferred by sibutramine can lead to serious risks for overweight and obese patients. Studies showed that increased weight contributes to chronic inflammation, which is associated with nuclear damage (Scarpato et al., 2011). Chronic inflammation due to obesity coupled with anti-obesity treatment with sibutramine can substantially increase the oncogenic risk for these patients.

In summary, sibutramine is a mutagenic drug and its use should be avoided, as it can cause carcinogenic mutations (Fenech, 2000). The genotoxicity of sibutramine is time-use 
dependent, as genotoxicity increases with chronic use of the drug. Simultaneous delivery of $S$. maxima with sibutramine did not reduce the mutagenic potential of the anti-obesity drug. Therefore, it is necessary to develop novel anti-obesity drugs without the potential for DNA damage.

\section{Conflicts of interest}

The authors declare no conflict of interest.

\section{REFERENCES}

ANVISA (2014). Avalible at [http://portal.anvisa.gov.br/wps/content/anvisa+portal/anvisa/sala+de+imprensa/menu++noticias+anos/2014+noticias/anvisa+aprova+novo+regulamento+tecnico+para+anorexigenos].

Araldi R, Rechiutti B, Mendes T, Ito E, et al. (2014). Mutagenic potential of Cordia ecalyculata alone and in association with Spirulina maxima for their evaluation as candidate anti-obesity drugs. Genet. Mol. Res. 13: 5207-5220.

Araldi R, Melo T, Mendes T, De-Sá-Júnior P, et al. (2015). Using the comet and micronucleus assays for genotoxicity studies: A review. Biomed Pharmacother. 72: 74-82.

Ayres M, Ayres M Jr and Ayres DL (2007). BioEstat 5.0 - Aplicações estatísticas nas áreas de ciências biológicas e médicas. Socieda Civil Mamirauá, Belém.

Bleier L, Wittig I, Heide H, Steger M, et al. (2015). Generator-specific targets of mitochondrial reactive oxygen species. Free Radic Biol. Med. 78: 1-10.

Brambilla G and Martelli A (2009). Update on genotoxicity and carcinogenicity testing of 472 marketed pharmaceuticals. Mutat. Res. 681: 209-229.

Carlini E, Galduróz J, Silva A and Al E (2007). II levantamento domiciliar sobre o uso de drogas psicotrópicas no Brasil: estudo envolvendo as 108 maiores cidades do país - 2005. Páginas \& Letras, São Paulo.

Delay M (2002). Arthrospira maxima (Spirulina maxima (Stiz.) Geitl.,1930) Acı Lake Strain. J. Fish Acquat. Sci. 19: $241-245$.

Eroglu E, Gemici G, Bayrak F, Kalkan A, et al. (2009). Acute myocardial infarction in a 24-year-old man possibly associated with sibutramine use. Int. J. Cardiol. 137: e43-e45.

FDA (2010). Available at [http://www.fda.gov/Safety/MedWatch/Safetylnformation/SafetyAlertsforHumanMedicalProducts/ ucm228830.htm].

Fenech M (2000). The in vitro micronucleus technique. Mutat. Res. 455: 81-95.

Fenech M (2011). Cytokinesis-block micronucleus cytome assay in lymphocytes. Methods Mol. Biol. 682: $217-34$.

Garcia-Bournissen F, Shrim A and Koren G (2007). Exposure to sibutramine during pregnancy. Can. Fam. Physician. 53: 229-230.

Gutiérrez-Rebolledo G, Galar-Martínez M, García-Rodríguez R, Chamorro-Cevallos G, et al. (2015). Antioxidant effect of Spirulina (Arthrospira) maxima on chronic inflammation induced by Freund's complete adjuvant in rats. J. Med. Food 00: 1-7.

Halford J (2011). Pharmacotherapy for obesity. J. Korean Med. Assoc. 54: 409-418.

Hanahan D and Weinberg R (2011). Hallmarks of cancer: the next generation. Cell Elsevier Inc. 144: 646-674.

Kang J and Park C (2012). Anti-obesity drugs: A review about their effects and safety. Diabetes Metab. J. 36: 13.

Kirsch-Volders M, Sofuni T, Aardema M, Albertini S, et al. (2003). Report from the in vitro micronucleus assay working group. Mutat. Res. 540: 153-163.

Krishna G, Urda G, Paulissen J. Historical vehicle and positive control micronucleus data in mice and rats. Mutat. Res. 453: 45-50.

Lee J, Teoh T and Lee T (2008). Catatonia and psychosis associated with sibutramine: A case report and pathophysiologic correlation. J. Psychosom. Res. 64: 107-109.

Luque C and Rey J (2002). The discovery and status of sibutramine as an anti-obesity drug. Eur. J. Pharmacol. 440: 119-128.

Martinez-Outschoorn UE, Curry JM, Ko Y-H, Lin Z, et al. (2013). Oncogenes and inflammation rewire host energy metabolism in the tumor microenvironment: RAS and NFKB target stromal MCT4. Cell Cycle 12: 2580-2597.

Miranda M, Cintra R, Barros S, Mancini-Filho J (1998). Antioxidant activity of the microalga Spirulina maxima. Brazilian J. Med. Biol. Res. 31: 1075-1079.

Nisoli E and Carruba M (2000). An assessment of the safety and efficacy of sibutramine, an anti-obesity drug with a novel mechanism of action. Obes. Rev. 1: 127-139.

Nojimoto F, Piffer R, Kiguti L, Lameu C, et al. (2009). Multiple effects of sibutramine on ejaculation and on vas deferens and seminal vesicle contractility. Toxicol. Appl. Pharmacol. 239: 233-240. 
Padwal R and Majumdar S (2007). Drug treatments for obesity: orlistat, sibutramine, and rimonabant. Lancet 369: 71-77.

Ponce-Canchihuamán J, Pérez-Méndez O, Hernández-Muñoz R, Torres-Durán P, et al. (2010). Protective effects of Spirulina maxima on hyperlipidemia and oxidative-stress induced by lead acetate in the liver and kidney. Lipids Health Dis. 9: 35.

Reczek C and Chandel N (2015). ROS-dependent signal transduction. Curr. Opin. Cell Biol. 33: 8-13.

Rubio M, Gargallo M, Millán A, Moreno B (2007). Drugs in the treatment of obesity: sibutramine, orlistat and rimonabant. Public Health Nutr. 10: 1200-1205.

Samanta S and Dey P (2012). Micronucleus and its applications. Diagn. Cytopathol. 40: 84-90.

Scarpato R, Verola C, Fabiani B, Bianchi V, et al. (2011). Nuclear damage in peripheral lymphocytes of obese and overweight Italian children as evaluated by the gamma-H2AX focus assay and micronucleus test. FASEB J. 25: 685-693.

Scheen A (2011). Sibutramine on cardiovascular outcome. Diabetes Care 34 (Suppl 2): 114-119.

Schieber M and Chandel N (2014). ROS function in redox signaling and oxidative stress. Curr. Biol. 24: R453-R462.

Shechter M, Beigel R, Freimark D, Matetzky S, et al. (2006). Short-term sibutramine therapy is associated with weight loss and improved endothelial function in obese patients with coronary artery disease. Am. J. Cardiol. 97: 1650-1653.

Silva C, Santos $\mathrm{J}$ and Takahashi C (2010). An evaluation of the genotoxic and cytotoxic effects of the anti-obesity drugs sibutramine and fenproporex. Hum. Exp. Toxicol. 29: 187-197.

Snyder R and Green J (2001). A review of the genotoxicity of marketed pharmaceuticals. Mutat. Res. 488: 151-169. 